\title{
Hydrogeochemistry and distribution of potentially toxic elements in a metallogenic province - The Iberian Pyrite Belt, Portugal
}

\author{
Patricia Gomes ${ }^{1}$, Teresa Valente ${ }^{1, *}$, Maria Rosário Costa $^{2}$, Rita Fonseca $^{3}$, Ana \\ Costa $^{1}$,Orquidea Neves $^{4}$, and Filipa Moreno ${ }^{1}$ \\ ${ }^{1}$ ICT, Institute of Earth Sciences, Pole of the University of Minho, 4710 Braga, Portugal \\ ${ }^{2}$ Departamento de Geologia, UTAD, Vila Real; GeoBioTec., Universidade de Aveiro \\ ${ }^{3} \mathrm{ICT}$, Institute of Earth Sciences, University of Évora, 7000Évora, Portugal \\ ${ }^{4}$ Centro de Recursos Naturais e Ambiente), Universidade de Lisboa, 1049 Lisbon, Portugal
}

\begin{abstract}
Contamination by acid drainage is an environmental problem in mineralized regions, especially in the surroundings of sulphide mines. The water rock interaction process involves the oxidative dissolution of sulphides, naturally or by mining activity, that generates acidity which, in turn, produces sulfate, and water pollution by sulphide-hosted metals. The particular geology of the Iberian Pyrite Belt (IPB) in the southwestern Iberian Peninsula creates the ideal conditions for such water contamination. Different water types were sampled at 28 locations across the entire IBP metallogenetic province. Anions, metals, and arsenic were analysed to assess the influence of acid drainage. The results demonstrate the sulfate nature of waters in the vicinity of mines. Other types of water in the IPB region are mainly mixed chloride and bicarbonate (river and groundwater) and mixed and sodium-bicarbonate (lakes) types. Water quality assessment indicated strong contamination of surface waters that are directly influenced by mine wastes. There is the additional concern that some lakes and groundwaters exhibit concentrations of potentially toxic elements (e.g. Al, As) that are above the regulatory limits established by the European Commission Water Framework Directive.
\end{abstract}

\section{Introduction}

In areas of water scarcity, such as across the Mediterranean region, protection of water resources is a major management concern. However, certain anthropogenic activities, like mining exploitation, is characterized by its potential for water contamination by toxic elements (e.g. metals and arsenic) through the production of acid mine drainage (AMD). This phenomenon occurs by oxidative dissolution of sulphide minerals that generates acidity which, in turn, produces sulfate, and water pollution by sulphide-hosted metals. The eco-toxic behaviour of metals like $\mathrm{Cu}, \mathrm{Zn}, \mathrm{Cd}$, and As when so mobilized, is a major

\footnotetext{
*Corresponding author: teresav@dct.uminho.pt
} 
environmental problem because it results in ecosystem disruptions. Additionally, these elements can be carcinogenic and, therefore, also pose a threat to human health.

In metallogenetic provinces with massive sulphide deposits, natural processes of acid rock drainage (ARD) may occur, promoting pollution of the water bodies or increasing the values of the background for potentially toxic elements. The IPB in the southwestern Iberian Peninsula is an example of a world-class metallogenic province [1,3]. AMD caused by historic mining, as well as ARD associated with natural oxidation of sulphides, has resulted in unique manifestations of water contamination [e.g., 4].

The semi-arid climate of the region enhances the value of natural water resources [5]. Water-rock interaction in heavily mineralized environments like the IPB may affect the hydrogeochemistry of local water bodies and groundwater. Consequently, assessment of water quality is of major importance in such geologic settings. This study of different water sources across the IPB identified the hydrochemical facies of the Portuguese sector of the IPB and documented the occurrence of potentially toxic elements across the entire metallogenetic province.

\section{Methodology}

\subsection{Study area}

The IPB (Figure 1), which contains more than 90 different volcanogenic massive sulphide ore deposits, extends through the Portuguese and Spanish portions of the Iberian Peninsula [3]. The study area corresponds to the Portuguese sector of the IPB, extending across all metallogenic province.

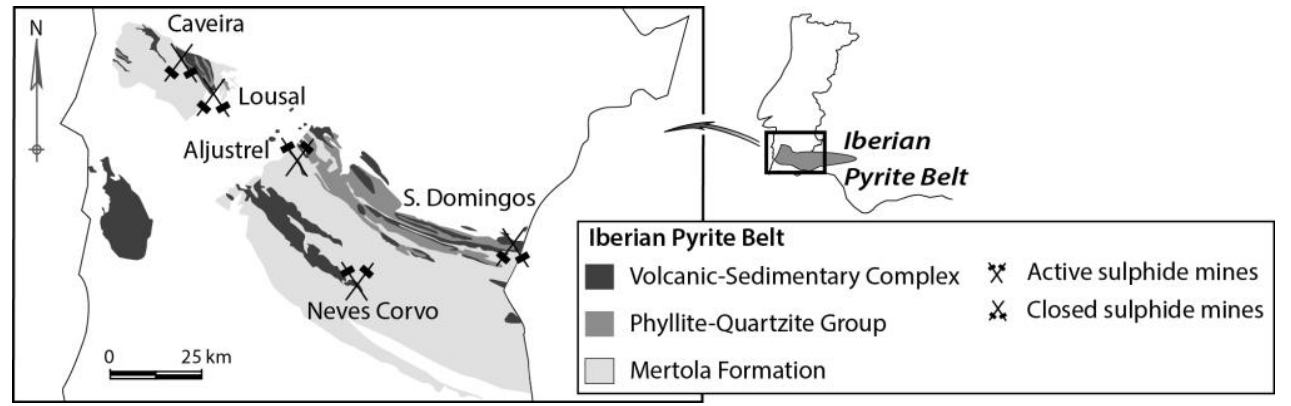

Fig. 1. Iberian Pyrite Belt with location of major closed and active mines.

The tectonostratigraphic sequence of the IPB comprises a lithology containing phyllites, siltstones, quartzites and quartzwackes (Phylito-Quartzite - PQ Group); volcanic felsic, intermediate and mafic rocks and sediments such as black shales, siliceous shales, jasper and chert (Volcano-Sedimentary complex); and shale, greywacke and conglomerates of Flysch group within the Mértola Formation [6]. The geology, mining history, and environmental issues of the IPB have been well studied [7].

Because of its location in the Mediterranean region, the IPB has a semi-arid climate and is one of the driest regions in SW Europe. The region is subject to regular, severe droughts. As a consequence, water supply is strongly dependent on public and private water reservoirs, 20 of which comprise an area $>10$ ha [5]. Nevertheless, wells are needed to satisfy water requirements. 


\subsection{Sampling and analytical methods}

The sampling network for this study comprised 28 locations and consisted of both surface and groundwater sources. Groundwater sources sampled were wells and boreholes used for drinking and irrigation. Surface waters included rivers and reservoir lakes for public water supply. A special surface water type of particular interest to this study was mine waters located around the mining complexes, including pit lakes, acidic lagoons, and AMD-streams. Sampling occurred in February 2018, immediately after the first rains. Temperature, electrical conductivity (EC), pH, and redox potential (Eh) were measured "in situ". After collection, the samples were transported to the laboratory under refrigerated conditions $\left(<4^{\circ} \mathrm{C}\right)$. Total acidity and alkalinity were analysed within 24 hours of collection after sampling by volumetric determination [8]. Anionic composition was determined by ion chromatography. Metals and arsenic were analysed, in an aliquot acidified $(\mathrm{pH}<2)$ in the field, by inductively coupled plasma optical emission spectrometry. The limits of detection were $0.01 \mathrm{mg} / \mathrm{L}$ and $0.005 \mathrm{mg} / \mathrm{L}$ for As and for the potentially toxic metals, respectively. The measurement precision was within relative standard deviation (RSD) of 5\% for all determinations.

\section{Results and discussion}

Table 1 presents a statistical summary of the parameters that globally describe the water properties throughout the province. The great standard deviation indicates the existence of very different types of waters. For example, the $\mathrm{pH}$ varies from very acidic (1.78) until neutral to alkaline (max. $\mathrm{pH}$ 9.71). The same is observed for sulfate, presenting a ratio between maximum and minimum higher than 7000. Such a variance is also reflected in the hydrochemical facies represented in the Piper diagram of Figure 2.

Table 1. Statistical summary for water samples from IPB (Ac = acidity; Alk = alkalinity).

\begin{tabular}{|c|c|c|c|c|c|c|c|}
\hline \multirow{2}{*}{ Parameters } & \multicolumn{4}{|c|}{ All samples across IPB $(n=28)$} & $\begin{array}{l}\text { Rivers and } \\
\text { Lakes }\end{array}$ & $\begin{array}{c}\text { Ground- } \\
\text { water }\end{array}$ & $\begin{array}{c}\text { AMD } \\
\text { waters }\end{array}$ \\
\hline & Min & Max & Average & STD & \multicolumn{3}{|c|}{ Average } \\
\hline $\mathrm{pH}$ & 1.78 & 9.71 & 5.92 & 2.54 & 7.88 & 7.54 & 2.73 \\
\hline $\mathrm{EC}(\mu \mathrm{S} / \mathrm{cm})$ & 277.4 & 27570 & 3827 & 6191 & 913.1 & 1136 & 8926 \\
\hline $\mathrm{Ac}(\mathrm{mg} / \mathrm{L} \mathrm{CaCO})_{3}$ & 143.0 & 78625 & 10238 & 24152 & - & - & 10238 \\
\hline Alk (mg/L CaCO 3$)$ & 55.75 & 328.5 & 159.7 & 75.72 & 134.7 & 224.4 & - \\
\hline $\mathrm{SO}_{4}(\mathrm{mg} / \mathrm{L})$ & 10.49 & 80691 & 4380 & 15269 & 158.5 & 76.76 & 12007 \\
\hline $\mathrm{Cl}(\mathrm{mg} / \mathrm{L})$ & 11.10 & 467.5 & 142.8 & 94.78 & 111.2 & 173.6 & 171.3 \\
\hline $\mathrm{Na}(\mathrm{mg} / \mathrm{L})$ & 22.25 & 378.2 & 122.8 & 74.11 & 108.0 & 137.9 & 131.1 \\
\hline $\mathrm{Ca}(\mathrm{mg} / \mathrm{L})$ & 11.47 & 584.1 & 130.5 & 159.7 & 64.78 & 59.87 & 247.8 \\
\hline $\mathrm{Mg}(\mathrm{mg} / \mathrm{L})$ & 9.21 & 928.7 & 135.6 & 212.8 & 41.40 & 55.34 & 296.2 \\
\hline $\mathrm{Al}(\mathrm{mg} / \mathrm{L})$ & 0.207 & 3098 & 164.5 & 583.0 & 0.325 & 0.309 & 459.9 \\
\hline $\mathrm{Fe}(\mathrm{mg} / \mathrm{L})$ & 0.016 & 41022 & 1757 & 7754 & 0.370 & 0.155 & 4918 \\
\hline $\mathrm{Mn}(\mathrm{mg} / \mathrm{L})$ & 0.005 & 168.6 & 20.49 & 43.71 & 0.113 & 0.020 & 57.20 \\
\hline $\mathrm{Cu}(\mathrm{mg} / \mathrm{L})$ & 0.016 & 1445 & 58.55 & 272.2 & 0.085 & 0.050 & 163.8 \\
\hline $\mathrm{Zn}(\mathrm{mg} / \mathrm{L})$ & 0.017 & 841.4 & 49.04 & 160.4 & 0.134 & 0.076 & 137.1 \\
\hline $\mathrm{Cd}(\mathrm{mg} / \mathrm{L})$ & 0.005 & 7.942 & 0.385 & 1.503 & 0.005 & 0.005 & 1.069 \\
\hline As $(\mathrm{mg} / \mathrm{L})$ & 0.010 & 141.3 & 5.988 & 26.71 & 0.178 & 0.172 & 16.45 \\
\hline $\mathrm{Pb}(\mathrm{mg} / \mathrm{L})$ & 0.005 & 9.200 & 0.511 & 1.784 & 0.005 & 0.005 & 1.422 \\
\hline $\mathrm{Ni}(\mathrm{mg} / \mathrm{L})$ & 0.002 & 1.924 & 0.325 & 0.572 & 0.010 & 0.032 & 0.861 \\
\hline Co $(\mathrm{mg} / \mathrm{L})$ & 0.004 & 25.50 & 1.388 & 4.821 & 0.006 & 0.008 & 3.874 \\
\hline
\end{tabular}


Figure 2(a) shows a 'Piper diagram' for a set of samples that are mainly sulfate waters (magnesium and mixed-sulfate types) that have been affected by AMD. Fresh surface waters (Rivers and Lakes) display higher variability in their anionic and cationic composition. River samples are mainly of mixed chloride and bicarbonate type. However, there are two samples, located near the mines of Caveira and Neves Corvo, which are of a mixed sulfate type. By contrast, freshwater lakes comprise mixed and sodium-bicarbonate types. The contents of the main anions in groundwaters lead to mixed, sodium chloride and sodium bicarbonate compositions in Figure 2(a).
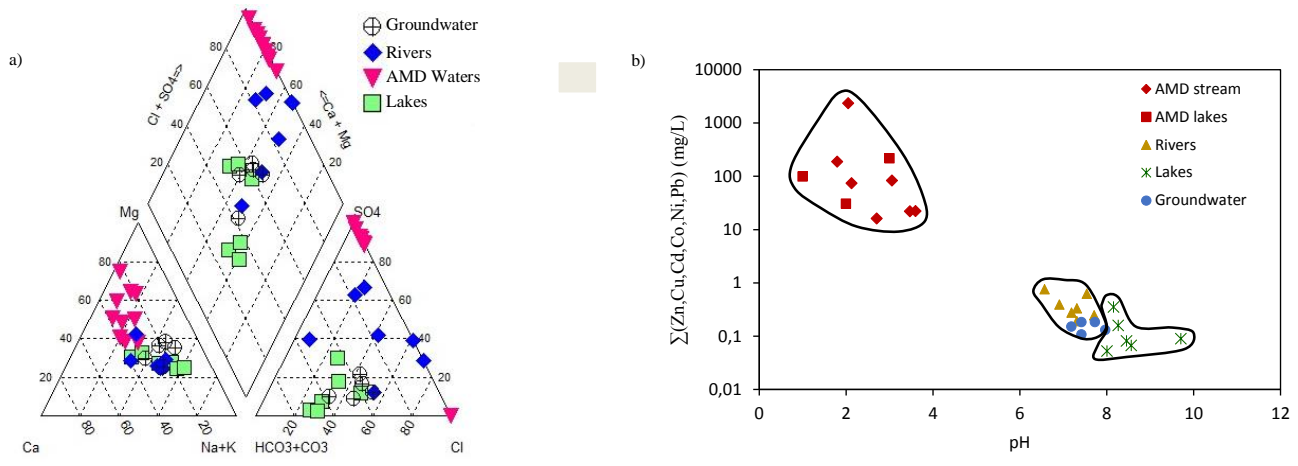

Fig. 2. (a) Piper diagram and (b) Ficklin diagram.

The diversity of water types displayed in the Piper is also illustrated by the 'Ficklin diagram' (Figure 2b). The sulfate mine waters define a distinct group in the upper left portion of this plot that is characterized by extremely low $\mathrm{pH}$ and high total metal concentration. Different types of mine waters (deep pit lakes, acidic lagoons, and small streams) are not distinguishable in the diagram, as all waters reflect the influence of waterrock interactions responsible for AMD production in a similar way. By contrast, uncontaminated surface waters and groundwaters reflect some clustering that corresponds to the water type. Among both types, the lakes are distinguished by their more alkaline nature. The slightly higher metal content of rivers may reflect a sulphide influence from mine waters ultimately draining into the river networks. The lower levels of contamination observed for constructed reservoirs contrasts with the IPB in Spain [7, 9].

Freshwater lakes, which represent the constructed reservoirs, are the main water sources of potable water [5]. Groundwater is typically used for irrigation, but occasionally also for the drinking supply. Therefore, using box plots, figure 3 compares the concentration of potentially toxic elements with the quality standards for the water sources aimed to produce drinking water.

The legal framework is met for metals like $\mathrm{Cu}, \mathrm{Pb}$, and $\mathrm{Ni}$. However, all samples exceeded permissible regulatory levels for $\mathrm{Al}, \mathrm{As}$, and $\mathrm{Zn}$ in both surface and groundwater. There are a variety of differences for the other metals. For example, groundwater samples with $\mathrm{Fe}$ higher than the first quartile do not meet the legal values, but samples with $\mathrm{Fe}$ lower than the third quartile for fresh lakes comply with quality standard.

\section{Conclusion}

This study focused on understanding the chemical character of waters sources in a mineralized region with long tradition of metal exploitation that has both closed and active mines. Characterization of surface and groundwater throughout the metallogenetic province was undertaken toward this objective. The results demonstrate the sulfate nature of the surface waters around the mining complexes and confirm the effect of AMD- 
contamination. However, we also observed that artificial lakes and groundwater across the region may, in certain circumstances, also be subject to acid drainage as a consequence of water rock interaction related to sulphide oxidation.

The dissolved concentrations of metals in the reservoirs and groundwater were compared with regulatory frameworks. This assessment provided some cause for concern, as $\mathrm{Al}, \mathrm{As}$, and $\mathrm{Zn}$ were elevated above permitted values in both surface and groundwater.
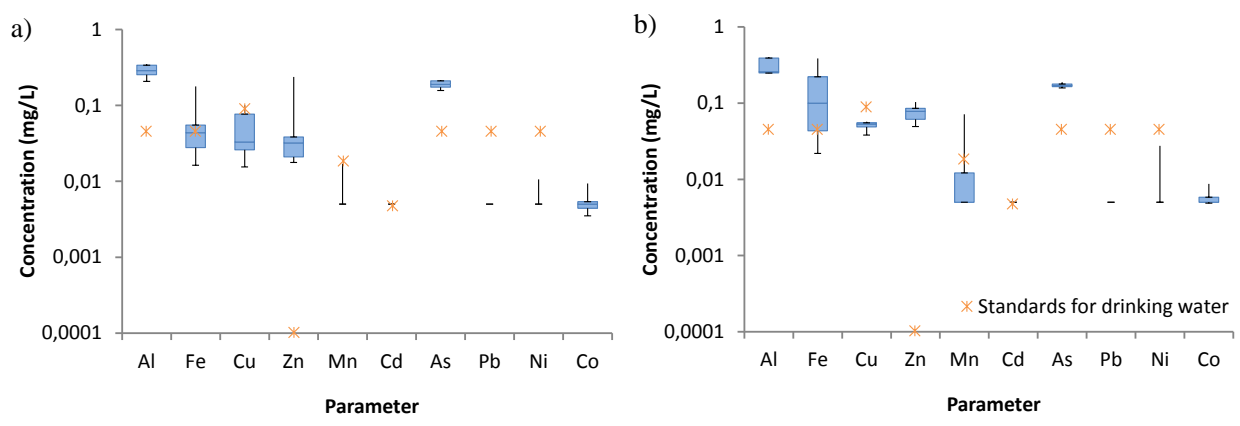

Fig. 3. Box plots for water reservoirs (a) and groundwater (b) with projection of legal standards for water sources aimed to produce drinking water $(*)$.

This work was co-funded by the European Union through the European Regional Development Fund, based on COMPETE 2020 - project ICT (UID/GEO/04683/2013) with reference POCI-01-0145FEDER-007690 and project Nano-MINENV number 029259.

\section{References}

1. J. Barriga, et al., Soc Econ Geol, Field Conf, Neves Corvo, Guidebook, $27-1$ (2007)

2. J.M. Leistel, et al., BRGM, Doc 234. (1994)

3. J. Relvas, et al., Soc Econ Geo., Spec. Pub 9, 155-176 (2002)

4. T. Valente, et al., App Geochem, 39, 11-25 (2013)

5. P. Gomes, et al., Env Proc, 4, 707-725 (2018)

6. R. Sáez, et al., Miner Dep. 34, 549-570 (1999)

7. J.A. Grande, et al., Mine Water Environ, 37, 211-216 (2018)

8. APHA, Standard Methods for Examination of Water and Wastewater, Am Water Works Assoc, Washington, DC (2012)

9. M. Santisteban, et al., Hydrol Res, 46, 156-167 (2015) 